\title{
Simulasi Monthe Carlo dalam Perkiraan Keuntungan Penjualan Pulsa Berbasis Web
}

\author{
Widiarti Rista Maya*, Elfitriani*, Fitra Alami Ndruru* \\ * Program Studi Sistem Informasi, STMIK Triguna Dharma
}

\begin{abstract}
Abstrak
Bisnis pulsa dikenal masyarakat sebagai kebutuhan penting yang sangat di butuhkan pada era zaman sekarang terlebih untuk setiap orang yang telah mengenal teknologi yang makin berkembang. Dengan perkembangan zaman yang semakin pesat membuat kebutuhan akan pulsa semakin meningkat dan menyebabkan penyediaan kebutuhan ini semakin marak, contoh kasus ini adalah penjualan pulsa pada SMA Shop yang setiap bulannya mengalami perkembangan terhadap pendapatan. Namun usaha ini masih memperkirakan keuntungan transaksi secara manual sedangkan zaman sudah semakin canggih dan sudah ada beberapa pengembangan usaha yang prosesnya menggunakan beberapa aplikasi.

Dalam membantu pengembangan nya peneliti menggunakan salah satu metode simulasi yaitu dengan metode Monthe Carlo yang terdiri dari analis, perancangan dan pengembangan. Analisis dan perancangan aplikasi ini menggunakan UML (Unified Modelling Language), Aplikasi ini dikembangkan ke dalam sistem Berbasis Web dengan Xampp yang didalamnya dapat dibuat database MySql . Peneliti mengharapkan aplikasi ini dapat membantu keefisiensi dalam pengembangan usaha terutama dalam perkiraan keuntungan penjualan pulsa pada SMA Shop.
\end{abstract}

Kata kunci : Simulasi, Monthe carlo, UML (Unified Modelling Language), MySql, Xampp dan berbasis web

\section{PENDAHULUAN}

Indonesia adalah negara besar yang ditandai dengan jumlah penduduk yang besar dan wilayah yang cukup luas, hal ini sangat baik bagi kita selaku orang-orang yang berjiwa bisnis. Ditambah lagi Indonesia juga termasuk negara konsumen, dengan bermodalkan tinggal di negara besar dengan masyarakat yang bersifat konsumtif kita semua dapat dengan relatif mudah mengembangkan bisnis retail [1]. Salah satu bisnis retail yang populer adalah pendistribusian voucher isi ulang pulsa. [2]Semakin banyaknya pengguna telepon genggam membuat kebutuhan akan pulsa semakin meningkat, bahkan saat ini pulsa tidak terbatas lagi hanya untuk penggunaan menelepon dan sms namun juga untuk pembelian paket data Untuk memprediksi tingkat keuntungannya maka diperlukan teknik simulasi salah satunya adalah metode Monthe Carlo yang menguraikan pendapatan keuntungan maka peneliti akan mengembangkan penerapan simulasi perkiraan keuntungan penjualan pulsa dengan metode Monthe Carlo Berbasis Web yang dapat memecahkan masalah pada perkiraan finansial Simulasi Monte Carlo dan dilakukan Berbasis Web yang akan memudahkan pihak perusahaan dalam melakukan pemeriksaan atau pengecekan terhadap keuntungan usaha dimana dan kapanpun. 


\section{METODOLOGI PENELITIAN}

\subsection{Metode Penelitian}

Makna Metodologi dalam Penelitian yang bertujuan untuk mengingatkan untuk para peneliti akan pentingnya penggunaan metode sebagai alat untuk menghadapi fenomena dan mencari kebenaran pengetahuan. Didalam metode penelitian ini terdapat beberapa langkah yaitu Data Collecting atau pengumpulan data, dan study of literatur atau studi kepustakaan. Berikut metode peneliti yang digunakan dalam penelitian ini adalah :

1. Teknik Pengumpulan Data (Data Collecting)

Adapun beberapa teknik yang digunakan dalam pengumpulan data dari penelitian yaitu :

a. Pengamatan (Observasi)

Observasi merupakan teknik pengumpulan data yang dilakukan dengan cara melakukan tinjauan langsung ke tempat study kasus dimana akan dilakukan penelitian.

Tabel 3.1 Data primer dari SMA Shop Cell

\begin{tabular}{|c|c|c|c|c|c|c|}
\hline \multirow[b]{2}{*}{ No } & \multirow[b]{2}{*}{ Jenis Pulsa } & \multicolumn{4}{|c|}{ Jumlah penjualan bulan November 2019} & \multirow[b]{2}{*}{ Total } \\
\hline & & $\begin{array}{c}\text { Minggu } \\
\text { ke-1 }\end{array}$ & $\begin{array}{c}\text { Minggu } \\
\mathrm{ke}-2\end{array}$ & $\begin{array}{c}\text { Minggu } \\
\text { ke-3 }\end{array}$ & $\begin{array}{c}\text { Minggu ke- } \\
4\end{array}$ & \\
\hline 1 & Telkomsel & 50 & 40 & 60 & 30 & 180 \\
\hline 2 & Indosat & 40 & 60 & 30 & 20 & 150 \\
\hline 3 & $\mathrm{XL}$ & 25 & 55 & 50 & 30 & 160 \\
\hline 4 & Axis & 60 & 40 & 60 & 40 & 200 \\
\hline 5 & Tri & 50 & 30 & 40 & 35 & 155 \\
\hline 6 & Esia & 40 & 45 & 35 & 50 & 170 \\
\hline 7 & Fleksi & 40 & 20 & 40 & 20 & 120 \\
\hline
\end{tabular}

Table 3.2 Daftar harga jual keseluruhan berdasarkan jenis pulsa

\begin{tabular}{|l|l|l|}
\hline No & \multicolumn{1}{|c|}{ Jenis Pulsa } & \multicolumn{1}{c|}{ Harga jual } \\
\hline 1 & Telkomsel & $\operatorname{Rp~} 1.732 .000$ \\
\hline 2 & Indosat & $\operatorname{Rp~} 1.300 .000$ \\
\hline 3 & XL & $\operatorname{Rp} 2.520 .000$ \\
\hline 4 & Axis & $\operatorname{Rp~} 3.300 .000$ \\
\hline 5 & Tri & $\operatorname{Rp~} 1.200 .000$ \\
\hline 6 & Esia & $\operatorname{Rp~} 1.000 .000$ \\
\hline 7 & Fleksi & $\operatorname{Rp~} 500.000$ \\
\hline
\end{tabular}

Tabel 3.3 Urutan penjualan pulsa

\begin{tabular}{|l|l|l|l|l|l|l|r|}
\hline \multirow{2}{*}{ No } & \multicolumn{7}{|c|}{ Jumlah penjualan bulan November 2019 } \\
\cline { 2 - 8 } & Telkomsel & Indosat & XL & Axis & Tri & Esia & Fleksi \\
\hline 1 & 50 & 40 & 25 & 60 & 50 & 40 & 40 \\
\hline 2 & 40 & 60 & 55 & 40 & 30 & 45 & 20 \\
\hline 3 & 60 & 30 & 50 & 60 & 40 & 35 & 40 \\
\hline 4 & 30 & 20 & 30 & 40 & 35 & 50 & 20 \\
\hline
\end{tabular}

Dari data perjualan tersebut maka akan menjadi penentu dalam simulasi perkiraan penjualan pulsa. Dengan langkah-langkah yang digunakan :

Tabel 3.3 Langkah-langkah penyelesaian

\begin{tabular}{|l|l|}
\hline No & \multicolumn{1}{|c|}{ Keterangan } \\
\hline 1 & Menentukan distibusi probabilitas dan distribusi probabilitas kumulatif \\
\hline 2 & Menentukan interval acak \\
\hline 3 & Melakukan percobaan \\
\hline 4 & Tentukan hasil perkiraan \\
\hline
\end{tabular}


2. Studi Kepustakaan (Library Search)

Dalam studi literatur banyak menggunakan jurnal baik dari jurnal internasional, jurnal nasional, jurnal lokal maupun buku referensi lainnya yang berkaitan dengan penelitian sebagai referensi, studi pustaka merupakan metode pengumpulan data yang diarahkan kepada pencarian data dan informasi melalui dokumen-dokumen, baik dokumen tertulis, foto-foto, gambar, maupun dokumen elektronik yang dapat mendukung dalam proses penulisan.

2.2 Metode Perancangan Sistem

Unsur yang penting dalam penelitian adalah metode perancangan sistem, khususnya dalam perancangan sistem yang menggunakan software atau perangkat lunak, perangkat lunak menggambarkan aktivitas pengembangan dalam sistem.

Algoritma sistem merupakan penjelasan langkah-langkah dalam menyelesaikan masalah Flowchart Algoritma Dari Metode Monthe Carlo

Gambar 2.1 Flowchart

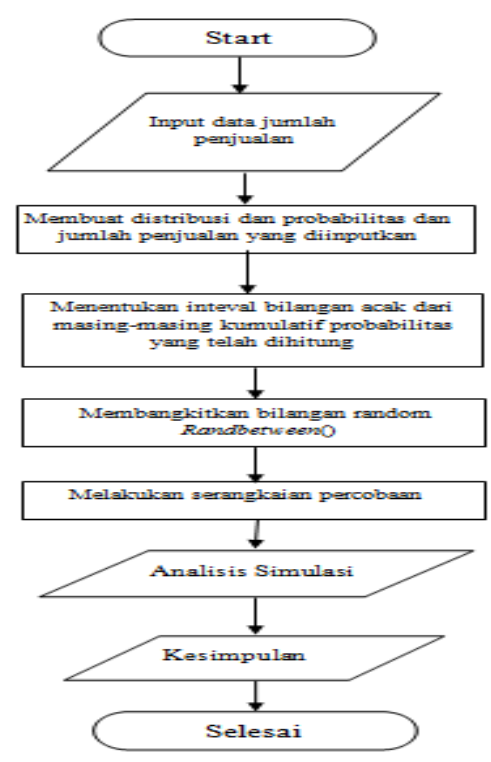

penyelesaian metode Monthe Carlo

\section{ANALISA DAN HASIL}

\subsection{Analisa}

Dibawah ini adalah tahapan perhitungan dengan metode Monthe Carlo:

a. Menentukan distibusi probabilitas dan distribusi probabilitas kumulatif

Tabel 3.5 Probabilitas dan Probabilitas Kumulatif

\begin{tabular}{|c|c|c|c|}
\hline \multirow{2}{*}{ No } & \multicolumn{3}{|c|}{ Jumlah penjualan bulan November 2019} \\
\hline & Telkomsel & Probabilitas & Probabilitas Kumulatif \\
\hline 1 & $50 / 180$ & 0.28 & 0.28 \\
\hline 2 & $40 / 180$ & 0.22 & 0.50 \\
\hline 3 & $60 / 180$ & 0.33 & 0.83 \\
\hline 4 & $30 / 180$ & 0.17 & 1.00 \\
\hline
\end{tabular}

Tabel 3.5 Probabilitas dan Probabilitas Kumulatif (Lanjutan)

\begin{tabular}{|c|c|c|c|}
\hline \multirow{2}{*}{ No } & \multicolumn{3}{|c|}{ Jumlah penjualan bulan November 2019} \\
\hline & Indosat & Probabilitas & Probabilitas Kumulatif \\
\hline 5 & $40 / 150$ & 0.22 & 0.22 \\
\hline 6 & $60 / 150$ & 0.33 & 0.55 \\
\hline 7 & $30 / 150$ & 0.17 & 0.72 \\
\hline 8 & $20 / 150$ & 0.11 & 0.83 \\
\hline
\end{tabular}


Tabel 3.5 Probabilitas dan Probabilitas Kumulatif (Lanjutan)

\begin{tabular}{|c|c|c|c|}
\hline \multirow[b]{2}{*}{ No } & \multicolumn{3}{|c|}{ Jumlah penjualan bulan November 2019} \\
\hline & $\mathrm{XL}$ & Probabilitas & $\begin{array}{c}\text { Prob. } \\
\text { Kumulatif }\end{array}$ \\
\hline 9 & $25 / 160$ & 0.16 & 0.16 \\
\hline 10 & $55 / 160$ & 0.34 & 0.50 \\
\hline 11 & $50 / 160$ & 0.31 & 0.81 \\
\hline 12 & $30 / 160$ & 0.19 & 1.00 \\
\hline
\end{tabular}

Tabel 3.5 Probabilitas dan Probabilitas Kumulatif (Lanjutan)

\begin{tabular}{|c|c|c|c|}
\hline \multirow[b]{2}{*}{ No } & \multicolumn{3}{|c|}{ Jumlah penjualan bulan November 2019} \\
\hline & Axis & Probabilitas & $\begin{array}{c}\text { Prob. } \\
\text { Kumulatif }\end{array}$ \\
\hline 13 & $60 / 200$ & 0.3 & 0.3 \\
\hline 14 & $40 / 200$ & 0.2 & 0.5 \\
\hline 15 & $60 / 200$ & 0.3 & 0.8 \\
\hline 16 & $40 / 200$ & 0.2 & 1.0 \\
\hline
\end{tabular}

Tabel 3.5 Probabilitas dan Probabilitas Kumulatif (Lanjutan)

\begin{tabular}{|l|l|r|l|}
\hline \multirow{2}{*}{ No } & \multicolumn{3}{|l|}{ Jumlah penjualan bulan November 2019 } \\
\cline { 2 - 4 } & \multicolumn{1}{|c|}{ Tri } & Probabilitas & Probabilitas Kumulatif \\
\hline 17 & $50 / 155$ & 0.32 & 0.32 \\
\hline 18 & $30 / 155$ & 0.19 & 0.51 \\
\hline 19 & $40 / 155$ & 0.26 & 0.77 \\
\hline 20 & $35 / 155$ & 0.23 & 1.00 \\
\hline
\end{tabular}

Tabel 3.5 Probabilitas dan Probabilitas Kumulatif (Lanjutan)

\begin{tabular}{|c|c|c|c|}
\hline \multirow{2}{*}{ No } & \multicolumn{3}{|c|}{ Jumlah penjualan bulan November 2019} \\
\hline & Esia & Probabilitas & Probabilitas Kumulatif \\
\hline 21 & $40 / 170$ & 0.24 & 0.24 \\
\hline 22 & $45 / 170$ & 0.26 & 0.50 \\
\hline 23 & $35 / 170$ & 0.21 & 0.71 \\
\hline 24 & $50 / 170$ & 0.29 & 1.00 \\
\hline
\end{tabular}

Tabel 3.5 Probabilitas dan Probabilitas Kumulatif (Lanjutan)

\begin{tabular}{|c|c|c|c|}
\hline \multirow{2}{*}{ No } & \multicolumn{3}{|c|}{ Jumlah penjualan bulan November 2019} \\
\hline & Fleksi & Probabilitas & Probabilitas Kumulatif \\
\hline 25 & $40 / 120$ & 0.33 & 0.33 \\
\hline 26 & $20 / 120$ & 0.17 & 0.50 \\
\hline 27 & $40 / 120$ & 0.33 & 0.83 \\
\hline 28 & $20 / 120$ & 0.17 & 1.00 \\
\hline
\end{tabular}


b. Menentukan Interval Acak

Tabel 3.6 Interval bilangan acak dari probabilitas kumulatif

\begin{tabular}{|l|r|l|l|}
\hline \multirow{2}{*}{ No } & \multicolumn{3}{|c|}{ Jenis Pulsa Telkomsel } \\
\cline { 2 - 4 } & Probabilitas & Probabilitas Kumulatif & Interval Bilangan acak \\
\hline 1 & 0.28 & 0.28 & $0-27$ \\
\hline 2 & 0.22 & 0.50 & $28-49$ \\
\hline 3 & 0.33 & 0.83 & $50-82$ \\
\hline 4 & 0.17 & 1.00 & $83-100$ \\
\hline
\end{tabular}

Tabel 3.6 Interval bilangan acak dari probabilitas kumulatif(lanjutan)

\begin{tabular}{|c|c|c|c|}
\hline \multirow{2}{*}{ No } & \multicolumn{3}{|c|}{ Jenis Pulsa Indosat } \\
\hline & Probabilitas & Probabilitas Kumulatif & Interval Bilangan acak \\
\hline 5 & 0.22 & 0.22 & $0-21$ \\
\hline 6 & 0.33 & 0.55 & $22-54$ \\
\hline 7 & 0.17 & 0.72 & $55-72$ \\
\hline 8 & 0.11 & 0.83 & $72-100$ \\
\hline
\end{tabular}

Tabel 3.6 Interval bilangan acak dari probabilitas kumulatif(lanjutan)

\begin{tabular}{|l|l|l|l|}
\hline \multirow{2}{*}{ No } & \multicolumn{3}{|c|}{ Jenis Pulsa XL } \\
\cline { 2 - 4 } & \multicolumn{1}{|c|}{ Probabilitas } & Probabilitas Kumulatif & \multicolumn{1}{|c|}{ Interval Bilangan acak } \\
\hline 5 & 0.22 & 0.22 & $0-21$ \\
\hline 6 & 0.33 & 0.55 & $22-54$ \\
\hline 7 & 0.17 & 0.72 & $55-72$ \\
\hline 8 & 0.11 & 0.83 & $72-100$ \\
\hline
\end{tabular}

Tabel 3.6 Interval bilangan acak dari probabilitas kumulatif(lanjutan)

\begin{tabular}{|l|l|l|l|}
\hline \multirow{2}{*}{ No } & \multicolumn{3}{|c|}{ Jenis Pulsa Axis } \\
\cline { 2 - 4 } & Probabilitas & Probabilitas Kumulatif & Interval Bilangan acak \\
\hline 13 & 0.3 & 0.3 & $0-2$ \\
\hline 14 & 0.2 & 0.5 & $3-4$ \\
\hline 15 & 0.3 & 0.8 & $5-7$ \\
\hline 16 & 0.2 & 1.0 & $8-10$ \\
\hline
\end{tabular}

Tabel 3.6 Interval bilangan acak dari probabilitas kumulatif(lanjutan)

\begin{tabular}{|c|c|c|c|}
\hline \multirow{2}{*}{ No } & \multicolumn{3}{|c|}{ Jenis Pulsa Tri } \\
\hline & Probabilitas & Probabilitas Kumulatif & Interval Bilangan acak \\
\hline 17 & 0.32 & 0.32 & $0-31$ \\
\hline 18 & 0.19 & 0.51 & $32-50$ \\
\hline 19 & 0.26 & 0.77 & $51-76$ \\
\hline 20 & 0.23 & 1.00 & $77-100$ \\
\hline
\end{tabular}


Tabel 3.6 Interval bilangan acak dari probabilitas kumulatif(lanjutan)

\begin{tabular}{|l|l|l|l|}
\hline \multirow{2}{*}{ No } & \multicolumn{3}{|c|}{ Jenis Pulsa Esia } \\
\cline { 2 - 4 } & \multicolumn{1}{|c|}{ Probabilitas } & Probabilitas Kumulatif & \multicolumn{1}{c|}{ Interval Bilangan acak } \\
\hline 21 & 0.24 & 0.24 & $0-23$ \\
\hline 22 & 0.26 & 0.50 & $24-49$ \\
\hline 23 & 0.21 & 0.71 & $50-70$ \\
\hline 24 & 0.29 & 1.00 & $71-100$ \\
\hline
\end{tabular}

Tabel 3.6 Interval bilangan acak dari probabilitas kumulatif(lanjutan)

\begin{tabular}{|l|l|l|l|}
\hline \multirow{2}{*}{ No } & \multicolumn{3}{|c|}{ Jenis Pulsa Fleksi } \\
\cline { 2 - 4 } & \multicolumn{1}{|c|}{ Probabilitas } & Probabilitas Kumulatif & \multicolumn{1}{c|}{ Interval Bilangan acak } \\
\hline 25 & 0.33 & 0.33 & $0-32$ \\
\hline 26 & 0.17 & 0.50 & $33-49$ \\
\hline 27 & 0.33 & 0.83 & $50-82$ \\
\hline 28 & 0.17 & 1.00 & $83-100$ \\
\hline
\end{tabular}

c. Membentuk bilangan acak

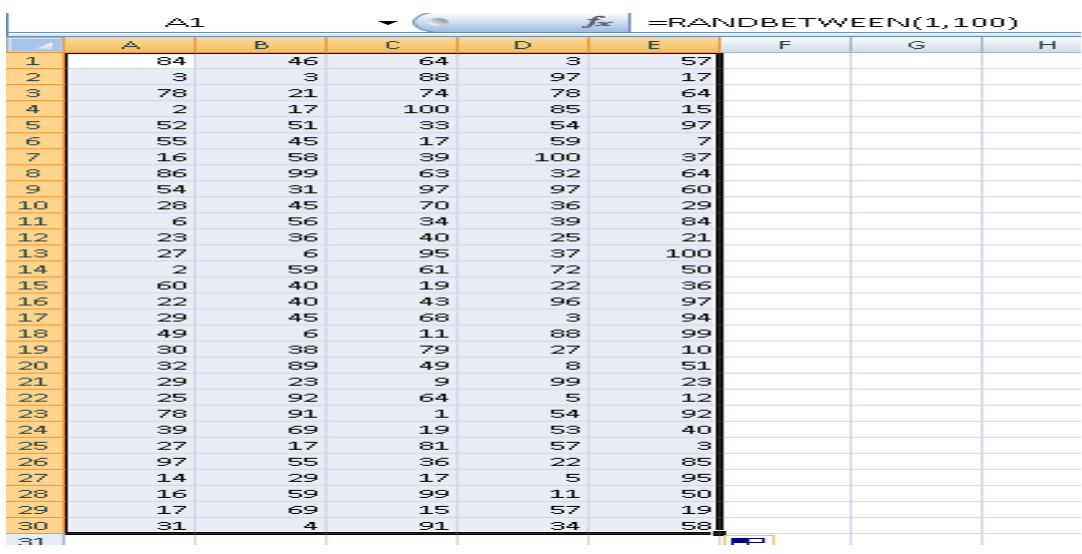

Gambar 3.2 Bilangan acak

d. Membuat simulasi dari rangkaian percobaan

Tabel 3.7 Jumlah penjualan (Simulasi)

\begin{tabular}{|c|c|c|c|c|c|c|c|c|}
\hline \multirow[t]{2}{*}{ Hari } & \multirow{2}{*}{$\begin{array}{l}\text { Angka } \\
\text { acak }\end{array}$} & \multicolumn{7}{|c|}{ Jumlah penjualan simulasi } \\
\hline & & Telkomsel & Indosat & $\mathrm{XL}$ & Axi & Tri & Esia & Fleksi \\
\hline 1 & 84 & 30 & 20 & 30 & 40 & 35 & 50 & 20 \\
\hline 2 & 3 & 50 & 40 & 25 & 40 & 50 & 40 & 40 \\
\hline 3 & 78 & 60 & 20 & 50 & 60 & 35 & 50 & 40 \\
\hline 4 & 2 & 50 & 40 & 25 & 60 & 50 & 40 & 40 \\
\hline 5 & 52 & 60 & 60 & 50 & 60 & 40 & 35 & 40 \\
\hline \multicolumn{2}{|c|}{ Total } & 250 & 180 & 180 & 320 & 210 & 215 & 140 \\
\hline
\end{tabular}

1. Rata rata permintaan pulsa telkomsel per Minggu : $250 / 5=50$

Cara ekspektasi:

$\mathrm{E}=\sum_{\mathrm{i}=0}^{4}($ Probabilitas dari pulsa $) x$ (permintaan pulsa) 
$(0.28(50)+0.22(40)+0.33(60)+0.17(30)=47.4$ atau $47 / \mathrm{minggu}$

2. Rata rata permintaan pulsa Indosat perminggu : $180 / 5=36$

Cara ekspetasi :

$\mathrm{E}=\sum_{\mathrm{i}=0}^{4}($ Probabilitas dari pulsa $) x$ (permintaan pulsa)

$0.22(40)+0.33(60)+0.17(30)+0.11(420)=35.9$ atau $36 / \mathrm{ming}$ gu

3. Rata rata permintaan pulsa XL per hari : $180 / 5=36$

Cara ekspektasi:

$\mathrm{E}=\sum_{\mathrm{i}=0}^{4}$ (Probabilitas dari pulsa) $x$ (permintaan pulsa)

$0.16(25)+0.34(55)+0.31(50)+0.19(30)=43.9$ atau 44/minggu

4. Rata rata permintaan pulsa Axis per hari : $320 / 5=64$

Cara ekspektasi:

$\mathrm{E}=\sum_{\mathrm{i}=0}^{4}($ Probabilitas dari pulsa $) x$ (permintaan pulsa)

$0.3(60)+0.2(40)+0.3(60)+0.3(40)=50 / \mathrm{minggu}$

5. Rata rata permintaan pulsa Tri per hari : $210 / 5=42$

Cara ekspektasi:

$\mathrm{E}=\sum_{\mathrm{i}=0}^{4}$ (Probabilitas dari pulsa) $x$ (permintaan pulsa)

$0.32(50)+0.19(30)+0.26(40)+0.23(35)=40.15$ atau $40 / \mathrm{minggu}$

6. Rata rata permintaan pulsa Esia per hari : $215 / 5=43$

Cara ekspektasi:

$\mathrm{E}=\sum_{\mathrm{i}=0}^{4}($ Probabilitas dari pulsa $) x$ (permintaan pulsa)

$0.24(40)+0.26(45)+0.21(35)+0.29(50)=43.15$ atau $43 / \mathrm{minggu}$

7. Rata rata permintaan pulsa Fleksi per minggu : $140 / 5=28$

Cara ekspektasi:

$\mathrm{E}=\sum_{\mathrm{i}=0}^{4}$ (Probabilitas dari pulsa) $x$ (permintaan pulsa)

$0.33(40)+0.17(20)+0.33(40)+0.17(20)=33.2$ atau 33/minggu

Untuk mencari perkiraan keuntungan penjualan (Simulasi) dapat dilakukan dengan :

\section{Harga jual keseluruhan jenis pulsa total penjualan jenis pulsa $X$ jumlah permintaan}

Dik : Telkomsel harga jual keseluruhan Rp.1.732.000 dan total keseluruhan penjualan sebanyak 180 maka :

$=\underline{1.732 .000} \times 50$

180

$=9.6 \times 50=480$

Hasil keseluruhannya dapat dilihat pada tabel dibawah ini :

Tabel 3.8

\begin{tabular}{|l|l|l|l|}
\hline No & Jenis Pulsa & $\begin{array}{c}\text { Jumlah } \\
\text { permintaan }\end{array}$ & \multicolumn{2}{|c|}{ Keuntungan } \\
\hline 1 & Telkomsel & 50 & Rp. 480.000 .00 \\
\hline 2 & Indosat & 36 & Rp. 312.012 .00 \\
\hline 3 & XL & 36 & Rp. 567.000 .00 \\
\hline 4 & Axis & 64 & Rp. 1.056.000.00 \\
\hline 5 & Tri & 42 & Rp. 312.564 .00 \\
\hline 6 & Esia & 43 & Rp. 252.962.00 \\
\hline 7 & Fleksi & 28 & Rp. 116.676 .00 \\
\hline $\begin{array}{l}\text { Total permintaan dan } \\
\text { keuntungan }\end{array}$ & 301 & Rp. 2.297.596.00 \\
\hline
\end{tabular}

perkiraan

keuntungan

penjualan pulsa

(Simulasi)/bulan

Dari tabel diatas Total keuntungan/bulan sebesar Rp. 2.297.596.00 


\subsection{Hasil}

Implementasi merupakan langkah yang digunakan untuk mengoperasikan sistem yang akan dibangun. Dalam bab ini akan dijelaskan bagaimana menjalankan sistem yang telah dibangun tersebut. Implementasi sebagai dukungan sistem analisa diperlukan beberapa perangkat-perangkat sebagai berikut: 1. Tampilan Form Menu Utama

Berikut ini merupakan tampilan dari form menu utama yang merupakan tampilan yang akan dikunjungin oleh user sebelum login

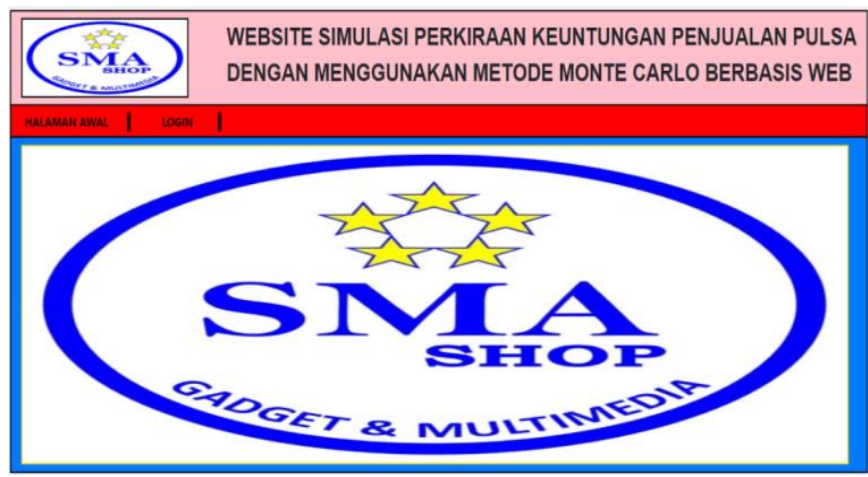

Gambar 3.3 Tampilan Menu Utama

2. Tampilan Form Login

Berikut ini merupakan Form Login tampilan dari sistem yang telah dibangun.

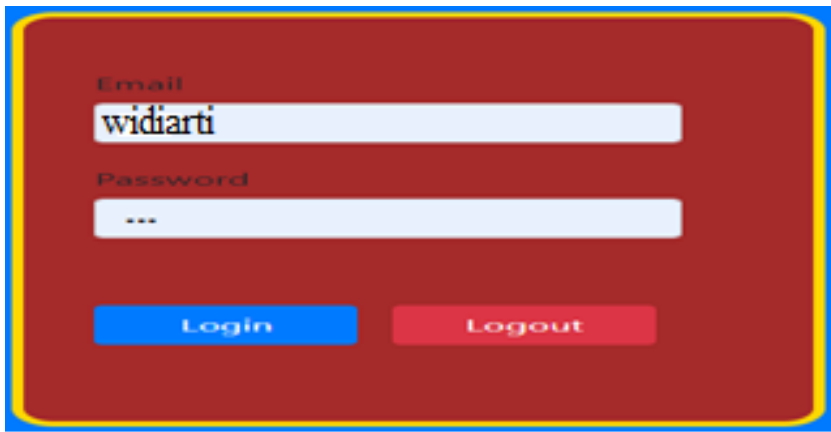

Gambar 3.4 Tampilan Form Login

3. Tampilan Form Menu Utama Pengolahan Data Pulsa

Berikut ini adalah tampilan form menu utama pengolahan data pulsa

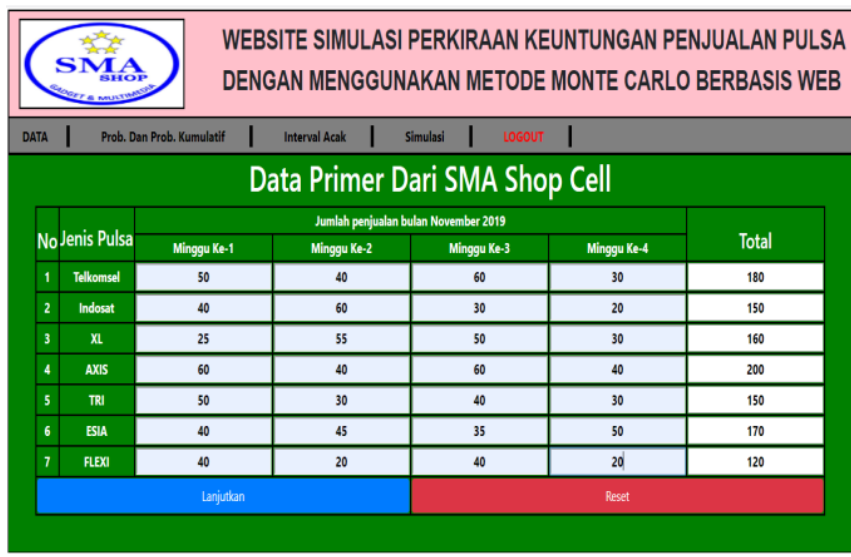

Gambar 3.4 Tampilan Form Data Penjualan

4. Tampilan Form Probabilitas dan Probabilitas Kumulatif

Berikut ini adalah Tampilan form Probabilitas dan Probabilitas Kumulatif yaitu: 


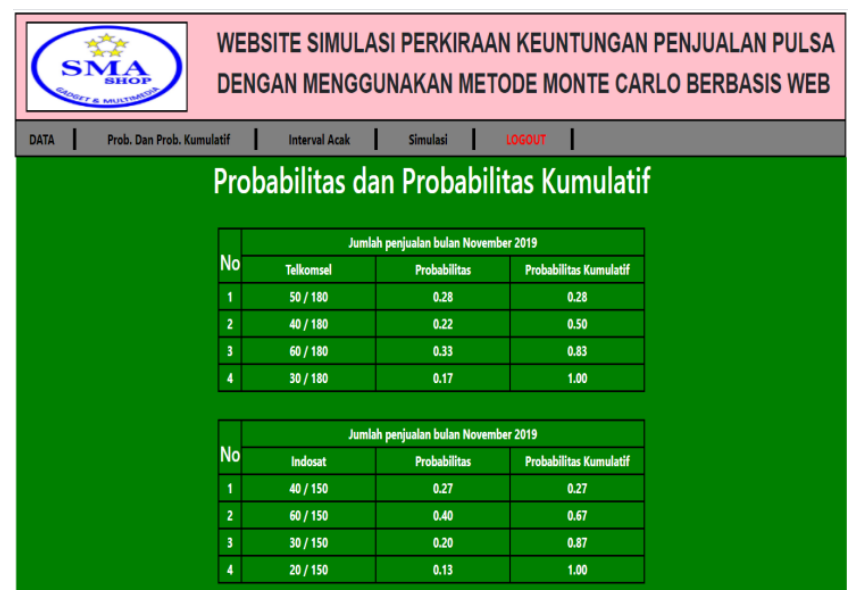

Gambar 3.5 Tampilan Form Probabilitas dan Probabilitas Kumulatif

5. Tampilan Form Interval Acak

Berikut ini adalah tampilan Form Interval Acak yaitu :

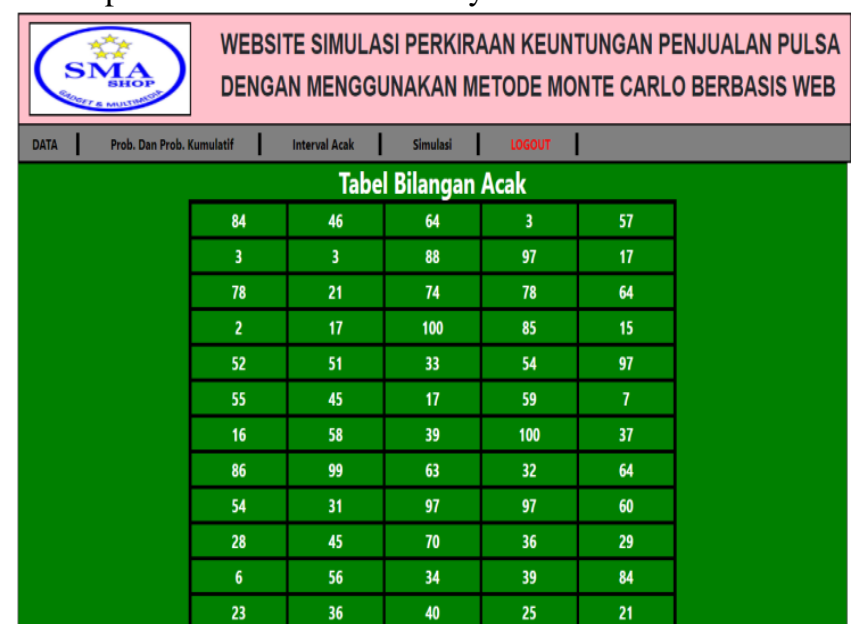

Gambar 3.6 Tampilan Form Interval Acak

6. Tampilan Form Simulasi

Berikut ini adalah Tampilan Form Simulasi :

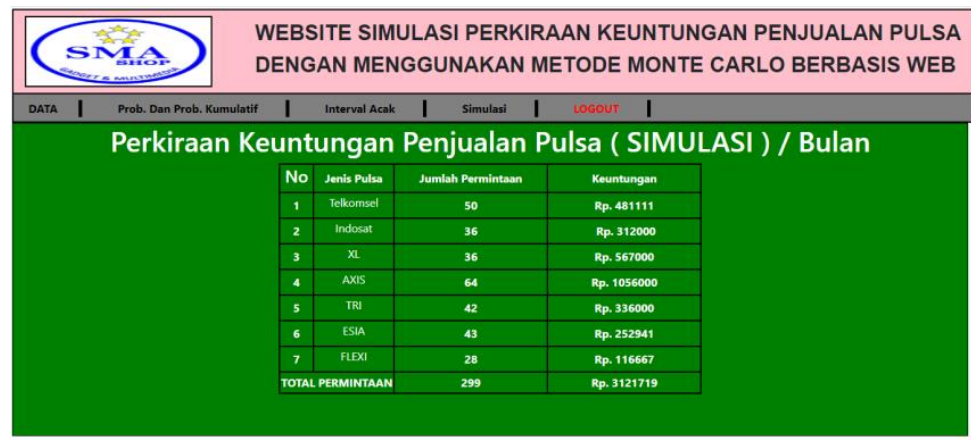

Gambar 3.7 Tampilan Form Simulasi 


\section{KESIMPULAN}

Dari hasil pembahasan dari Bab 1 sampai Bab 5 mengenai simulasi perkiraan keuntungan penjualan pulsa dengan menggunakan metode monthe carlo berbasis web dapat diambil kesimpulan adalah sebagai berikut:

1. Berdasarkan pengujian dan implementasi terhadap simulasi perkiraan keuntungan penjualan pulsa dengan menggunakan metode monthe carlo berbasis web maka perkiraan keuntungan dapat dilakukan dengan mudah.

2. Berdasarkan hasil analisa, metode monthe carlo dapat diterapkan dalam pemecahan masalah pada SMA SHOP dalam hal perkiraan keuntungan.

3. Berdasarkan penelitian, dalam upaya memodelkan simulasi dengan metode monthe carlo yang dirancang diawali dengan analisis masalah kebutuhan kemudian dilakukan pemodelan.

4. Dengan menggunakan bahasa pemrograman web dan database Mysq laplikasi simulasi dengan metode monthe carlo dapat dirancang.

5. Aplikasi yang dibagun dapat dijalankan oleh user dengan menggunakan setiap tahapan yang ada mulai dari input data pulsa, mencari probabilitas dan probabilitas kumulatif, interval acak, sampai uji coba,pada proses metode Monthe Carlo.

\section{UCAPAN TERIMA KASIH}

Terima kasih kepada rekan-rekan sejawat beserta pihak-pihak lainnya yang mendukung penyelesaian jurnal ini.

\section{REFERENSI}

[1] “1,2 1, 2*," vol. 3, no. 2, pp. 111-121, 2018.

[2] Y. E. Praptiningsih, W. W. Ariestya, and N. Mustaufa, "PERANCANGAN SISTEM PENJUALAN PULSA," vol. VIII, no. 2, 2016.

[3] P. Silindak, D. Menggunakan, M. M. Carlo, I. Pendahuluan, and M. Monte, "Prediksi penjualan barang pada koperasi pt. perkebunan silindak dengan menggunakan metode monte carlo," vol. 3, no. 6, pp. 65-69, 2016.

[4] I. Masalah, "SIMULASI PERKIRAAN KEUNTUNGAN PENJUALAN," pp. 978-979, 2015.

[5] S. Disa and M. C. Mc, "SEPATU PER HARINYA DENGAN METODE MONTE CARLO ( STUDI KASUS TOKO SEPATU PRO SADIRA EDAR ),” pp. 1-5. 